\title{
Discretion in Social Welfare: The Uneasy Position in the Rule of Law
}

\author{
Joel F. Handler†
}

Prior to the routinization and bureaucratization of public welfare, the system could be loosely described as discretionary, professional, and decentralized. In general, eligibility was not clear-cut; budgets were individually determined. But even in those days, there were rules. Professionalization was the ideal, but most workers were in fact not professionals. And there were efforts at centralization at both the federal and state levels. Certainly as compared to the present, however, the public assistance programs had far more play.

What was that system like? Then, as now, there was great variety, but some generalizations can be made. Wisconsin was a benign, liberal system. Basic grants were relatively generous, there was an elaborate system of special grants to meet both emergency and rehabilitative goals, and there was a considerable degree of professionalism. In practice, however, the system was quite routinized. The special needs program was not utilized in any significant amount; it depended, for the most part, on client initiative and clients lacked information or were hesitant to ask. The caseworkers, a shifting sea of people who used their public assistance jobs as way stations, were not particularly interested in spending more agency resources or engaging in more paperwork. At that time, home visits were mandatory, but, for the overwhelming majority of recipients, the visit was pleasant and attitudes toward the caseworker were positive. For the most part, these were friendly, non-threatening social calls. But in the rare situation in which caseworkers did have control over something that the clients wanted, then negative feelings arose-feelings of dependency and coercion. ${ }^{1}$

The next example comes from Professor Mashaw's empirical work in Virginia, but is a story that has been found many times over in many parts of the country. These are the depressing tales of refusals to take

$\dagger$ Vilas Research Professor of Law, University of Wisconsin.

1. J. HANDLER \& E. HOLlingsWORTH, THE "DESERVING POOR": A STUDY OF WELFARE AD. MINISTRATION 119-28 (1971) (Wisconsin case study). Susan Sheehan's story of a Puerto Rican family on welfare illustrates most of these points. The mother enjoyed the caseworkers' visits. The workers (there were many changes) were pleasant, young, college-educated women, who did not know very much, but were nice to chat with. However, when the mother needed something-in her case, permission to move-her relationship with the workers became dominating, hostile, and ugly. S. SHEEHAN, A WELFARE MOTHER 19-24, 60-66 (1976). 
applications, harrassment of applicants and recipients, imposition of crude moralisms, midnight raids, threats to take away children. Protective rules were flouted with impunity. This is the story of racism, sexism, and traditional, long-standing hostility toward the "undeserving" poor. ${ }^{2}$

The third example involves the "welfare mess." Again, our time period is before the conservative reaction to welfare. In the large city departments, the offices simply became overwhelmed with numbers. Administration became chaotic, arbitrary, random. The concept of individual treatment broke down; many recipients experienced routinization, while many others got lost in the bedlam of the offices. Almost none had the professional recipient-caseworker relationship contemplated in the program. ${ }^{3}$

\section{I.}

These stories are familiar, but what are the underlying reasons and what implications do they have for the problems that we are now discussing? One could, of course, find many causes contributing to the manner in which large public programs developed, but I would like to stress three: volume, values, and the distribution of wealth and power. Volume need not detain us very long. It is a brutal fact of the welfare state. In the 1930's, we thought that welfare (public assistance) would wither away. Now, we have become reconciled to the fact that vast numbers of people in our society, as presently organized, will need financial and other assistance. This is especially true for the client group on which we focus: female-headed households. Volume is the cardinal enemy of discretion, professional judgment, individualization; heavy caseloads force routinization. All programs, if we are to be at all realistic, must deal with the problem of workload.

The second cause is far more important: Values and attitudes toward the poor are varied, long-standing, and greatly affect how the poor are treated. Society has always distinguished between the deserving and undeserving poor, those whose poverty is blameless and those who are blameworthy. In a prior age, the blind, the halt, and the lame were in the former category; those who could work but failed were in the latter. Today, the aged and the disabled have joined the former, but the non-

2. Sec, e.g., Mashaw, Welfare Reform and Local Administration of Aid to Families with Dependent Children in Virginia, 57 VA. L. REV. 818 (1971); Reich, Midnight Welfare Searches and the Social Security Act, 72 YALE L.J. 1347 (1963). An interesting contemporary example concerns the enforcement of criminal cohabitation statutes. The man-in-the-house rules were declared invalid by the Supreme Court in King v. Smith, 392 U.S. 309 (1968), and Lewis v. Martin, 397 U.S. 552 (1970), but the cohabitation statutes are enforced by local prosecutors. The choices offered in the plea bargain are to marry, to move out, or to get off welfare. Fineman, Law and Changing Patterns of Behavior: Sanctions on Non-Marital Cohabitation, 1981 WIS. L. REV. 275, 289-97.

3. Lipsky, Bureaucratic Disentitlement in Social Welfare, 58 SOC. SCI. REV., Mar. 1984, at 3. 
aged-the childless adults, and the female-headed households-are still the undeserving. It is not only the failure of work that draws the community's hostility; fueling the furies are race, sex, and various forms of deviant behavior and life style. ${ }^{4}$

Attitudes toward the poor are reflected in the organization and structure of programs. For pensioners, the Social Security system is federal, rule-bound, relatively evenhanded in its administration, and with little reported hassle. Similarly, now that the aged poor have passed the line from undeserving to deserving, their progam-Supplemental Security Income-which in the 1920's bristled with moralistic conditions, is also now federalized, relatively condition-free, and evenhanded. But programs for the undeserving are very different. They are state and local, discretionary, decentralized, and subject to a great many moralistic and punitive practices. In addition to the Aid to Families with Dependent Ghildren (AFDC) program discussed by Professor Simon, I am referring to General Assistance, and state and local emergency and special needs programs. The one exception to this pattern is the food stamps program, which has its own special history.

In sum, the organizational and structural arrangements of the public assistance programs are not accidental. Instead, they are profoundly affected by views on how to regulate deviant behavior in this country-the undeserving poor have always been considered deviant. ${ }^{5}$

The final cause of the ills of public assistance programs is the distribution of wealth and power. One can never forget that the people we are talking about are extremely dependent. They are ill-prepared to effectively participate in public programs, and, in particular, to understand the procedural systems designed to secure benefits and rights for them. The bureaucracy has control over the information, the resources, the staying power, the power of retaliation; workers, even if well-meaning, are pressed for time, short of money, and, in all honesty, feel that they know what is best for the clients. Discretion, in its lawful, positive sense (as distinguished from Professor Mashaw's examples from Virginia), implies, at the minimum, a discussion, a dialogue, a bargain of some sorts, a minimal sharing of power. But how are the poor, the really dependent poor, to participate in these decisions? And if they cannot cope when the administration of the program is benign and supporting, imagine their situation

4. See J. Handler, Reforming the POOR: Welfare Policy, Federalism, and Morality 138-41 (1972); J. PATTERSON, AMERICA's STRUGGLE AGAINST POVERTY 1900-1980, at 99-126 (1981); Rosenheim, Vagrancy Concepts in Welfare Law, in LAW OF THE POOR 187 (J. tenBroek ed. 1966).

5. See J. HANDLER \& E. HOLLINGSWORTH, supra note 1 , at 33-37; J. HANDLER, supra note 4, at 138; J. HANDLER \& M. SOSIN, LAST RESORTS: EMERGENCY ASSISTANCE AND SPECIAL NEEDS PRO. GRAMS IN PUBLIC WELFARE (1983). 
when it is hostile, abusive, and vindictive.

The old system of public assistance was predicated on individualism, professionalism, and decentralization, but the caseload and working conditions forced routinization at best, and chaos and arbitrariness more often. In this situation, hostile attitudes toward the undeserving poor, combined with extreme dependency, led to widespread abuses.

\section{II.}

It was against this depressing background that liberals attempted to reform welfare. The liberals sought to attack the three problems of volume, values, and distribution. To deal with the problem of volume, they pressed for the routinization of the welfare grant-called the consolidated or flat grant-based on the concept of horizontal equity. ${ }^{6}$ Advocates of horizontal equity recognized that concepts of equality of treatment ultimately depended on arbitrary inclusions and exclusions, but their central animating principle was that in light of the great arbitrariness and chaos of the welfare mess, more equality could be achieved through rough measures than through individualized treatment. But in doing so, they failed to pay enough attention to the need for emergency assistance to help those who could not get by on the flat grant. ${ }^{7}$

The second issue, the corrosive hostility toward the underserving poor, was addressed through a profound change in our legal culture, where relationships with government were reconceived from privileges to rights. Instead of discretionary decisions, officials could work out their own and the community's hostilities, citizens would be protected by substantive and procedural rules; they would be rights-bearing citizens, not supplicants. It was a re-conception of the poor; they were not deviant, they were not in need of rehabilitation. They needed income, not social services. ${ }^{8}$

The third issue, the distribution question, was to be handled by providing a full array of procedural protections to vindicate substantive rights, and legal and other advocacy services. ${ }^{\circ}$

The liberal program did not work out; maybe it was doomed from the start. Instead, the conservative approach carried the day. The flat grant did become nationwide, but grant levels (particularly in AFDC) were

6. Actually, the trend toward the consolidated grant had been established in the prior decade because of the workload pressure.

7. The development of the consolidated grant, its ideology, and its limitations, are discussed in J. HANDLER \& M. SOSIN, supra note 5, at 23-28.

8. Handler, Controlling Official Behavior in Welfare Administration, in LAW OF THE POOR, supra note 4, at 155, 157-58; Reich, The New Property, 73 YALE L.J. 733, 734-39 (1964).

9. J. HANDLER, E. HOLLINGSWORTH \& E. ERLANGER, LAWYERS AND THE PURSUIT OF LEGAL RIGHTS 185-89 (1978); Cahn \& Cahn, The War on Poverty: $A$ Civilian Perspective, 73 Yale L.J. $1317,1344-52$ (1964). 
kept low, and only pitiful amounts of money went into special needs and emergency assistance programs. The result has been the rising demand on private charity-the food lines, the shelters. Legal services and other advocacy resources, never sufficient for the task, have been seriously curtailed. Negative attitudes toward the undeserving poor have been fueled; the current conservative policy is to further segregate and categorize, to increase the severity of the work test and of other conditions for receiving public assistance for this class. Then, in further efforts to reduce costs, the administrative practices that Professor Simon has described have been introduced. I agree with his description, but would add two additional comments: first, the utter chaos that one witnesses in the public assistance offices-the crowds, the waiting, the shouting, the maze of cubicles, the forms, the fear and resignation of the applicants, and the anger and frustration of the workers; second, that by forcing public assistance recipients to supplement their welfare grants by resorting to General Assistance and private charity-where available - the recipients are now confronting the most discretionary, moralistic public and private programs, in which there are virtually no legal protections.

III.

These are the realities of the administration of public assistance for the undeserving. What happened? What went wrong with the liberal program? Was it a failure of implementation or a failure in concept as well? One side of the story is familiar-the conservative takeover and the distortion of liberal ideals. But was this outcome inevitable?

As E.P. Thompson reminds us, any system of law in a society of great maldistributions of wealth and power will be suspect. ${ }^{10}$ We have many prominent examples. Our streets are filled with confused and pitiful wanderers who are not considered dangerous to themselves and others, and teenagers who, for whatever reason, no longer find home tolerable. Was it wrong or misconceived to insist that these people no longer remain locked in dungeons or red-brick institutions even though the liberals could not carry through and provide for community services? ${ }^{11}$ The answer is not clear.

Similar questions could be raised about the history of welfare reform. Faced with the arbitrariness, the abuses, and the randomness of the welfare system, was it wrong to press for horizontal equity, entitlements, legal services-in short, the rule of law? Was it wrong to think of the poor

10. E.P. THOMPSON, WHigs AND HuNTERS: THE ORIGIN OF THE BLACK ACT 258-69 (1975).

11. The story of the mentally ill is well known. For the deinstitutionalization of juvenile status offenders, see NEITHER ANGELS NOR THIEVES: STUDIES IN DEINSTITUTIONALIZATION OF STATUS OFFENDERS (J. Handler \& J. Zatz eds. 1982). 
as rights-bearing citizens entitled to the same procedural regularities as other citizens?

Events turned out badly in AFDC, mental health, for status offenders. One could name many other programs as well. But why? The liberals would blame the conservatives. Professor Simon apparently feels that the liberal program (the "dominant vision") is conceptually flawed; if not responsible for the transformation of public welfare, it helped pave the way. Most of the horror stories that he recounts, however, are the results of the zeal of the Reagan Administration. One can hardly blame the liberals for the current excesses.

The social reforms in public assistance were intimately connected to the broader changes in our legal culture starting with the civil rights movement of the mid-1950's and early 1960's. The ideology of that movement stretches all the way back to the foundations of liberalism. The liberal vision viewed man as autonomous and in an adversarial, conflictual relationship with the state. Under the rising market economy of the seventeenth and eighteenth centuries, man pursued his individual interests free from governmental restraints. ${ }^{12}$ The role of law was to protect the individual from the sovereign, to provide order and security in a competitive society. Neutral principles of law applied by an independent judiciary would curb the discretionary authority of the rulers; they, too, would be subject to the rule of law. Absolute monarchy ceased to the extent that law became absolute. In Nonet and Selznick's terms, law became autonomous. ${ }^{13}$ Through the use of autonomous law, rights would be enforced by reducing the discretionary powers of government. Government would be subject to law.

There is still a great deal to be said in favor of the liberal vision. Think of the Social Security retirement system. Despite its size, as far as I know, it is a relatively well-run, smoothly operating program. Would we want that system to be based on standards, decentralization, and profession rather than on rules, centralization, and routinization? Voter registration in the South used to be based on "organic social norms"; one of the great, -successful social reform efforts in recent decades has been the transformation of that system from discretion to rules. ${ }^{14}$ We witnessed a similar struggle in school desegregation. Other examples could be given. Professor Simon thinks that most of social order depends on the law not being enforced. Are we describing the same elephant? It seems to me that large

12. C. MACPHERSON, THE POLITICAL THEORY OF POSSESSIVE INDIVIDUALISM: HOBbes tO LOCKE 209-10 (1962).

13. P. NONET \& P. SELZNICK, LAW AND SOCIETY IN TRANSITION: TOWARD RESPONSIVE LAW 5354 (1978).

14. The reform effort in voting is described in J. HANDLER, SOCIAL MOVEMENTS AND THE LEGAL SYSTEM: A THEORY OF LAW REFORM AND SOCLAL CHANGE 103-53 (1978). 
areas of society are subject to relatively clear rules (both public and private); there is a vast amount of law abidingness and regularity.

The point, I think, is that some areas lend themselves to legal and bureaucratic routinization, while other do not. They do not because of the changed role of government. Liberal legalism has failed to take account of this change, and this, at least on a conceptual level, has contributed to the trends that Professor Simon has described. Let me explain.

The modern welfare state has changed the relationship of the citizen to the state. Instead of the old liberal vision of the individual asserting his independence from the state, we now see interdependence. We see relationships that are both continuous and discretionary-education, health, mental health, parts of welfare, social services, and so on.

The result of this change is that large numbers of citizens, of necessity, have to deal with the discretionary powers of officials on a more or less continuous basis, but, because of the maldistribution of wealth and power, they lack the capacity to deal with government in these situations. The result is familiar. Discretion becomes professionally or bureaucratically dominating. There is a loss of both substantive and procedural rights.

The liberal legalism vision of the relationship of the citizen to the state is individualistic, conflictual, adversarial. It seeks to achieve the values of individualism-autonomy, dignity, responsibility-through the assertion of rights vindicated in courts of law. This is the ideology of the legal rights revolution. But in areas where the social relationship between the citizen and the state is discretionary and continuous, the legal rights approach has not succeeded. It has failed conceptually and empirically.

The conceptual failure lies in that the situation calls for continuity and consensus whereas liberal legalism emphasizes a discontinuous, adversarial conflict. The empirical failure lies in the distribution of wealth and power. The bureaucracy has the information, the resources, the staying power, and because of the continuing relationship, the power of retaliation. Legal services and laws are not sufficient to overcome this imbalance. The empirical results of the operation of due process procedures in social welfare confirm these results. In many systems, including AFDC, procedural rights are routinely subverted by the bureaucracy. The harsh, negative values and attitudes toward the poor, the minorities, the weak, the deviant still work their way. The burdens of asserting the rule of law, especially in the discretionary, continuous relationship, are just too great for the vast majority of the poor. ${ }^{15}$

15. There is a large empirical literature documenting this point. See, e.g., D. BAUM, THE WELFARE FAMily aNd MASS ADMinistrative Justice $1-13$ (1974); J. HANDLER, PROTECTING THE SOCIAL SERVICE CliENT 47-69 (1979); Kirp, Buss \& Kuriloff, Legal Reforms of Special Education: Empirical Studies and Procedural Proposals, 62 CALIF. L. REV. 40, 117-23 (1974). 


\section{Comment on Simon}

Liberal legalism expresses our deepest ideals of individualism, freedom, and social ordering. In many areas, both historically and today, it has served us well, and in my opinion, will continue its vital, humanistic role. The inadequacy of liberal legalism is that it has tried to either stamp out discretion or control it through the adversarial assertion of legal rights, and this appproach is inappropriate for certain areas. ${ }^{16}$

Professor Simon would have us abandon liberal legalism altogether, in favor of standards, decentralization, and profession. But because he has not addressed the fundamental problems of volume, values, and distribution, his proposals are unsatisfactory. We are dealing with massive numbers of people and claims. While one should not reject proposals out of hand during the present period of economic stringency, we will never be in a world of unlimited resources, especially administrative resources for public welfare. It is always going to be a world of relative scarcity. At the minimum, then, one must pick and choose. There are large areas of public welfare that do lend themselves to routinization, where rules are efficacious, not perfect but reasonably satisfactory for most cases. In those areas, rules are preferable to a discretionary system of standards and decentralization.

A central, preliminary question is to determine which areas lend themselves to routinization and which areas require discretion. What are the criteria for deciding appropriateness? The next line of inquiry is to structure procedures for both routinization and discretion that will further the basic values of a liberal society.

While the liberal legal tradition founders over discretion, Professor Simon goes too far the other way. Without addressing the problems of volume, values, and the distribution of wealth and power, the direction he proposes (which has been tried in many situations) poses great dangers. $\mathrm{He}$ asserts that his system-the original understanding of the New Deal-was never tried; in fact, it was tried. It was the system prior to the legal rights revolution. In some areas of the country, it worked moderately well, but it also led to the widespread, serious abuses that became so familiar. Standards, professionalism, and decentralization foundered on the corrosion of volume, values, and power.

16. There is a question of whether some aspects of the legal rights changes in our culture could be characterized as "autonomous law" or "responsive law." Nonet and Selznick define responsive law as emphasizing purposiveness and participation, which is the thrust of much of public interest law. P. NONET \& P. SELZNICK, supra note 13, at 73-78; see B. WEISBROD, J. HANDLER \& N. KOMESAR, PUBLIC INTEREST LAW: AN ECONOMIC AND INSTITUTIONAL ANALYSIS 457-59 (1978). There was also a purposive and participatory aspect to welfare reform, but, by and large, I think that the dominant movement was toward the development of legally enforceable rights through the application of formal due process procedures. This movement was closer to autonomous than responsive law. See Teubner, Substantive and Reflexive Elements in Modern Law, 17 LAW \& Soc'Y REV. 239 (1983). 
Volume will, of necessity, produce routinization of practices. In a discretionary system, such practices will be unwritten. Thus, there will be even greater problems of indeterminacy and disparities in access to information. Standards and professionalism exacerbate the problems caused by society's values and attitudes towards the poor. First, there is at least some law abidingness in our society and rules influence some behavior in some situations. This restraint is lessened in a regime of standards (let alone organic social norms).

Second, the professions do not have an enviable record in fulfilling values of individualism. ${ }^{17}$ For example, the queen of the professions, medicine, is paternalistic in the extreme. It is solely the physician who makes the judgment as to what is in the best interests of the patient. The focus is strictly on outcomes, not on the decisionmaking process. Now it is true that there is a movement in medical ethics to change this approach, to move toward a balance between professional and patient autonomy and responsibility, to try to achieve genuine informed consent, but the movement's philosophy has not been accepted by the medical profession.

The training and orientation of professionals emphasizes their scientific expertise, that they have superior knowledge and judgment. And they are under time constraints as well. Professionals, whether in organizations or not, are busy, they are instrumental, and feel that ultimately they will be making the decision anyway.

In addition, the unequal distribution of power encourages professional domination. The poor and the near poor are at a considerable disadvantage in dealing with professionals. They often have feelings of insecurity, fears of imposing themselves, of taking up valuable time, of feeling stupid. Many legal services lawyers and physicians, as well as other professionals, who are fully committed to dialogue and patient autonomy complain of the frustrations in trying to get clients to take responsibility for their decisions. The inexorable social relation is that of dependency, and this fact casts serious doubt on the prospects of approaching the values of individualism in a regime of standards, decentralization, and profession. The only hope offered is that the professionals (officials) will change their ways. That is a thin reed; something more must be provided.

How, then, should we think about the issue of discretion in social welfare programs? People in roughly equal positions have no problems with discretion; they bargain, and for both parties to the bargain there is auton-

17. For medicine, see Katz, Informed Consent-A Fairy Tale?: Law's Vision, 39 U. PITT. L. REV. 137, 168-69 (1977). For mental health, see Rapapport, In Praise of Paradox: $A$ Social Policy of Empowerment over Prevention, AM. J. COMMUNITY PSYCHOLOGY 1, 15-21 (1981). For social work, see R. LubOVE, THE PROFESSIONAL Altruist 118-24 (1965); J. GALPER, THE POLITICS OF SOCLAL SERVICES 31-36 (1975). For law, see Spiegel, Lawyering and Client Decisionmaking: Informed Consent and the Legal Profession, 128 U. PA. L. REV. 41 (1979). 
omy, dignity, and responsibility. But the kind of rough equality that is necessary for this kind of relationship will not be achieved through the Legal Services Corporation or any other program of client resources in the likely future. As a realistic matter, the issue of discretion has to be faced in a world of dependency. This means paying more attention to structures and incentives to encourage and support the changes in attitudes that are necessary to make discretionary decisions compatible with liberal values.

First, let me make some suggestions in what I call mixed areas, where there has to be both routinization and discretion. The example I have in mind is public assistance. There, large areas, of necessity, have to be routinized. Volume alone dictates this result, but there also are affirmative reasons. There is considerable evidence that many people are comfortable with an adequate basic grant. (I emphasize adequate, because this research was done in a different time, and certainly these results would no longer be applicable when grants continue to decline in real terms.) Such people prefer to live their lives with a minimum of contact with government and take pride in their ability to manage, pretty much as they did before assistance. Now I do not want to exaggerate this point. There may be a sense of false pride, feelings of stigma, lack of information, and real suffering. Certainly, there is a problem of lack of expressed dissatisfaction. based on lack of awareness of opportunities. ${ }^{18}$ It is also true, however, that there are people who do want to get along on their own terms.

But this, of course, is not the whole problem. Although considerable areas of public assistance can be handled in a routinized way, there are also large areas where discretionary determinations have to be made. This is especially true for emergencies and special needs. Public assistance recipients run out of money because of unforeseen events (for example, diabetes), or because of mismanagement (a problem not confined to the poor, as all of us well know). A system of public assistance has to provide for individual, discretionary decisions to handle these emergencies and special needs.

Today, in an era of cutbacks and harshness toward the most vulnerable of our society, the bottom line public assistance programs are a disaster. The basic grants have been flattened and reduced dramatically in real terms; this is especially true of AFDC (although the effect has been mitigated somewhat by food stamps). But no attention has been paid to the emergency assistance and special needs programs. The programs that exist

18. For example, there appears to be a persistent problem in the take-up rate of the Supplemental Security Income program. Some who do not apply are close to the eligibility line, and the small amount of benefit might not be worth the cost, but this group by no means accounts for the discrepancy between potential eligibility and actual enrollment. Part of the explanation is that there are difficult problems of communication with the elderly poor. See J. HANDLER \& M. SOSIN, supra note 5 , at $237-42$. 
are extremely small, limited to a few items that do not involve "moral hazard," and most public assistance recipients have to rely on whatever General Assistance might have to offer, or on private charity. And, as already noted, the full force of society's negative attitudes toward the undeserving poor is manifest in this part of public and private assistance. ${ }^{10}$

A major failure of the liberal reformers was not to recognize the importance of maintaining a discretionary system for emergencies and special needs along with a system of entitlements. The failure is not confined to the United States. At the end of World War II, when the British installed the Beveridge reforms, the strong emphasis was on a system of entitlements with a basic, minimum floor. The vision of the government was that the poor were like everyone else, except that they lacked sufficient income resources. The concepts of discretion, professional assistance, and decentralization lost favor because they carried connotations that the poor were somewhat deviant and needed rehabilitation. But special needs and emergencies arise in real life, regardless of the vision of political leaders, and over time, so many recipients also received some form of discretionary assistance that on three separate occasions the entire system had to be overhauled. Despite this experience, the British still resist the idea that a bottom line public assistance program has to be both routinized and discretionary. They still insist that a large, massive program can only be fair if it is completely routinized. ${ }^{20}$

The first step toward creating a desirable mixed system is to recognize the importance of discretion, think about it constructively instead of as a necessary evil, and then design structures and incentives to make sure that it works properly and is capable of being monitored. I cannot go into details here, but will suggest that it may be that separate organizational structures, even private structures, would be desirable, that many items for special needs and emergencies can be prescribed by rules, and that in general professional assistance may not be necessary or desirable. ${ }^{21}$ Nonetheless, there still will remain the trouble spots. In particular, people will run out of money and need additional funds for items that were supposed to be covered by the basic grant-for example, rent, utilities, food, clothing. This happens all the time, but, of course, will occur far more frequently during times like the present. The English call this "double payments" and they raise the most difficult problems. Administrators fear the runaway quality of these demands and the disincentives to budget. The

19. See id. at 241 .

20. For a description of the British experience, see id. at 215-35.

21. See J. Handler, "Proportional" vs. "Creative" Justice-Discretionary Benefits in IncomeMaintenance Programs: The British Supplementary Benefits Scheme (Inst. for Research on Poverty, Univ. of Wisconsin, Discussion Paper No. 603-80, 1980). 
public and other recipients think it unfair that they have to get along on their grants when others are rewarded for either negligence or fraud. Nevertheless, the problem persists, and needs have to be met.

It would be primarily in this area that special units should be created, equipped with a high degree of professional training, operating under standards. The units would have to be decentralized so that they could operate flexibly and efficiently. In addition to helping these people, the demands made on these offices (as well as the other emergencies and special needs) should be viewed as a window on the operation of the basic program and other social and economic conditions facing the poor. This is where shortages in housing, rises in fuel prices and other necessities will appear. It will also indicate malfunctions in administration of the basic program. It will identify families that need professional help. ${ }^{22}$

There is another area where discretion is also needed. In thinking about the inadequacies of the routinized welfare system, we tend to focus on the recipient who comes for help, but we know that there are others who need help and do not ask. The problem is probably most acute with the elderly on public assistance. In England, for example, the elderly poor can have extra heating grants for the asking, but many do not ask and suffer. There are many reasons for the failure to ask, but to get them to ask is not simply a matter of providing information. Studies have shown that requests will only be made after intensive social work with a fairly high per capita administrative cost.

One of the curious ironies about emergency assistance and special needs programs is that the intense opposition to them seems to be out of proportion to their costs. In the United States, such programs are small and haphazard, so costs are not very relevant, but in England, where extensive programs did develop, they never accounted for more than about five to six percent of the total public assistance payments budget. ${ }^{23}$ Although roundly criticized as being administratively intensive, the administrative costs of these programs were comparable to those of their routinized counterparts. Nevertheless, discretionary programs are severely attacked from both the right and the liberal professional reformers. The right's attack is predictable. The liberal reformers insist that discretion is inconsistent with the ideal of rights-bearing citizens and that a large-scale public assistance

22. The fair hearing system can also be used as a window on the operation of the program, but again, one has to pay attention to structures and incentives. In Wisconsin, state district directors used to use fair hearing requests to help spot weaknesses in county administration. Handler, Justice for the Welfare Recipient: Fair Hearings in AFDC-The Wisconsin Experience, 43 SOC. SERV. REV. 12, 28-32 (1969). For a later use of negotiators, which contrary to state expectations increased the number of hearing requests, see Project, Procedural Due Process and the Welfare Recipient: A Statistical Study of AFDC Fair Hearings in Wisconsin, 1978 WIS. L. REV. 145.

23. J. HANDLER \& M. SOSIN, supra note 5, at 220-25. 
program cannot be both fair and discretionary.

The truth, of course, is that regardless of the liberal program, necessity requires a discretionary element. The question is whether this need will be openly acknowledged and programs restructured according to decent, humane values or, as in the United States, the public assistance recipients will be thrown to the mercies of General Assistance and private charity. But to bring the discretionary system out of the closet certainly does not imply that the routinization of public assistance has to be scrapped and the whole system reconverted into standards, decentralization, and profession.

IV.

I come now to the final point, that is, how to structure a discretionary decisionmaking process that reaches intelligent substantive decisions and, at the same time, enhances the autonomy, dignity, and responsibility of the participants.

I start with a concrete example in an area where I am currently working-special education. Special education decisions are discretionary and continuous. They are discretionary in the sense that we really do not know the causes for why children do not do well at school, or what to do for these children. ${ }^{24}$ Thus, the facts are indeterminate. The statute-the Education for All Handicapped Children $\mathrm{Act}^{25}$-is also indeterminate; it merely guarantees the right to an "appropriate" education. ${ }^{28}$ The decision is continuous in that the relationship lasts during the school life of the child.

Growing out of the changes in our legal culture previously described, the substantive right to an appropriate education is coupled with extensive procedural safeguards. An informed consent form has to be signed by the parent or guardian before every formal decision is taken by the school-the identification and selection of the child for testing, the evaluation conference and decision, the placement, the re-evaluation. If the parent objects, he is entitled to two administrative hearings-one at the school district level and one at the state level, and there is judicial review. ${ }^{27}$

Nationwide, the procedural system, for the most part, is a failure. The school system has the information, the professional expertise, and is sad-

24. See Placement in Public Education: Historical Developments and Current Procedures, in Placing ChIldRen in SPecial Education: A STRategy for Equity 23 (K. Heller, W. Holtzman \& S. Messick eds. 1982).

25. 20 U.S.C. $\$ \S 1400-1420,1453$ (1982).

26. Id. $\S 1400$.

27. See Bickel, Classifying Mentally Retarded Students: A Review of Placement Practices in Special Education, in PLACING CHILDREN IN SPECIAL EDUCATION, supra note 24, at 182, 209-13. 
dled with the resource constraints. Historically, the educational establishment was never keen about special education; it views its mission as the education of those students that will further its organizational goals; the Act was thrust upon it. Most parents, especially the ones that we are concerned about (the lower social classes, minorities) face tremendous odds in trying to cope with the school system. For many, having a handicapped child is a matter of shame and denial; they are only too glad if the school bus will take their child away for the day. For others, there is lack of understanding, fear of antagonizing the school people, fear of appearing stupid, or taking up valuable professional time. They do not understand the scientific jargon. The result is that many parents have contact with the schools but no real communication, they passively accept the school's decisions, they sign consent forms in blank, and the schools regard the Act's procedures as giving rise to unnecessary paperwork and bother-a situation totally predictable given the problems of volume, values, and the distribution of wealth and power. When the distribution is altered, the system is altered. Middle class and rich parents (or poor people with vigorous advocates) can and do use the system successfully when high stakes are involved-for example, forcing the school to provide an expensive private placement-but such situations are rare. ${ }^{28}$

The school district in Madison, Wisconsin, operates differently. ${ }^{20}$ The prevailing view there is that the system can succeed in helping a handicapped child only if the parent fully understands the nature of the problem. The Madison school people point out that the child spends only five or six hours each day in the school. For the Madison school people, informed consent is not an obstacle to be overcome, but is a positive organization goal. They implement this program by a series of informal conferences prior to the institution of the formal educational steps; these conferences take place at each stage of the process. Every decision is viewed as experimental and subject to evaluation and re-negotiation. Neither the parents nor the school people feel that they are in a zero-sum game. This immediately reduces the level of conflict and allows for negotiation and compromise. The attitude toward experimentation, combined with a healthy professional skepticism as to the state of the art, leads the school to be flexible as to a range of alternatives. If the parents really want plan $A$, the school will go along even though the school would prefer plan $B$, as long as plan $A$ is reasonable and the parties understand that all

28. Id. at 224-25.

29. The description of the Madison program is based on approximately twenty interviews I conducted with parents of handicapped children, parent advocates, the head of a citizens advocacy group specializing in special education, the director and assistant director of the program, teachers, social workers, and school psychologists. Additional interviews are being scheduled. This case study is part of larger work that I am engaged in, which explores alternative procedures for discretionary decisions. 
decisions will be re-evaluated. In those cases, the school regards the parents' cooperation as worth more than the additional benefits of plan $B$. Parents, on the other hand, also feel that particular decisions can be renegotiated, and can therefore afford to be flexible as well.

Well and good, but, given the distribution question, how can the parents participate in this process? Aren't they still subject to co-optation, and if this is true, aren't they in an even worse position than under the formal system? The school recognizes this problem and through oral and written communication, strongly encourages the parents to contact voluntary organizations that will supply parent advocates. The parent advocates themselves are usually parents of handicapped children and are knowledgeable volunteers. In addition, the state department of instruction also provides training sessions and workshops for parents of handicapped children.

The parent advocates attend the conferences and act on behalf of the parents. Why does the school district encourage this? In their words, the parent advocates do not have to be "polite." "They will ask questions that the parents are afraid to ask." And-this is the important point-it is out of this conflict that better communication and understanding will be achieved.

The Madison system, of course, is not perfect and there are many unanswered questions and problems, but at this point, I want to draw some generalizations to show two things: first, how this procedure differs from and is superior to the liberal legal model, and second, that to achieve individual values in this kind of procedure, one must go beyond standards, decentralization, and profession. ${ }^{30}$

The Madison procedure is consensual rather than conflictual. The goal is to reach a cooperative solution rather than to determine winners and losers. In a relationship that is both discretionary and continuous, this makes far more sense than adversarial advocacy, which is discontinuous, cross-sectional, and pulls the parties apart. As Stewart Macaulay has pointed out in his seminal work on the use of contract law in business relations: When businessmen want to continue to deal with each other, they bargain, they do not go to law. If the continuing relationship is worth preserving, they do not sue. ${ }^{31}$ With handicapped children, the relationship

30. The Madison system, of course, does not replace the Act's procedures, but only three formal appeals have been filed since 1974 . The research, however, is only preliminary. I still lack information on very crucial matters-for example, the number of conferences, the percentage of parents who in fact participate, caseloads, resources, and so forth. But the fact that there is a high degree of consensus among a variety of sources gives me some confidence that the description in the text is reasonably accurate. It is certainly accurate in theory.

31. Macaulay, Non-Contractual Relations in Business: A Preliminary Study, 28 AM. SOC. REV. $55,60-62$ (1963). 
continues. The question is whether it is alienating and dominating or is consensual and cooperative.

The Madison procedure is continuous rather than discontinuous. And again, this makes more sense. The procedure should last as long as the substantive relationship. This does not mean that there has to be one continuous conference, but it does mean frequent meetings, communication, and an experimental, flexible approach rather than finality.

The distributional issue is lessened if two conditions are fulfilled. If the parent advocate and the other resources are supplied (help and support from voluntary organizations and the state workshops) and if the school is interested in genuine informed consent, then the parent is in a better position to participate. But both conditions have to be fulfilled. If the school treats informed consent as an obstacle rather than as an organizational goal, then client resources will not be sufficient to overcome the advantages of the bureaucracy. The school has to want the parents to understand and agree.

How, though, is individualism to be preserved in this communitarian, consensual decisionmaking procedure? Here lies the special role of conflict-the use of the parent advocate. In adversarial relations, conflict and advocates are integral parts of the procedure. In cooperative or consensual systems, conflict is suppressed; it is negative, and, for this reason, there is considerable concern about the loss of autonomy and responsibility. ${ }^{32}$ The Madison system takes a unique approach to conflict. Conflict is necessary to gain consensus, to aid in communication and understanding. Conflict is a positive good, not something to be avoided. Conflict, in the form of the parent advocate, preserves individualism. It allows the parent to exercise autonomy, dignity, and responsibility. It is communicative conflict, not adversarial conflict.

The core of liberalism is that each individual is to be considered an end, never a means. Adversarial advocacy cannot meet this ideal; there is always a winner and a loser. Communal decisionmaking threatens the individualism of the participants, who may become means to the group decision. The Madison system, by treating genuine informed consent as an important organizational goal, overcomes the means-ends distinction; the school and the parents have to be both means and ends simultaneously. Conflict, structured into the consensual decisionmaking, is the mechanism by which the individualism of the parent is preserved.

32. See Mashaw, Administrative Due Process: The Quest for a Dignitary Theory, 61 B.U. L. REV. 885, 922-25 (1981).

In adversarial advocacy, it is assumed that individualism is preserved. Profesor Simon questions this assumption in a powerful critique. See Simon, The Ideology of Advocacy: Procedural Justice and Professional Ethics, 1978 WIS. L. REV. 29. 
To sum up, for many parts of the welfare system, as well as for other social programs, the ideals of the legal rights approach, I believe, are valid, necessary, and productive of much social good. But, as long as we have problems of volume, there will be routinization; it might as well be in the open and dealt with constructively.

For significant aspects of social welfare programs, discretion will be necessary, but more needs to be done than trying to refurbish the old system of standards, decentralization, and profession. The Madison school district experience suggests a model. We have to abandon the traditional view that discretion is incompatible with a liberal society, that individualism can be preserved only through adversarial advocacy. The suggestion is that autonomy, dignity, and responsibility can be enhanced in consensual decisionmaking through the positive use of conflict.

. There are other really knotty problems. A great deal more thought has to be given to the problems of informed consent in dependent relationships-what are its elements, what are its limits, how does one evaluate it in real life? Client resources (parent advocates, voluntary organizations, information, training) do not seem to raise great conceptual issues, and there is a great deal of experience from the past two decades to draw upon. The problem of organizational behavior, however, is far more elusive. How does one make the lower levels of the bureaucracy view informed consent in positive terms? This is not merely a question of attitudes; careful attention has to be paid to structures and incentives, to facilitate and reward flexibility and experimentation. As far as I can tell, this is still largely an unchartered area, but the problem has been recognized, promising real-life examples have been identified, and analysis has taken some preliminary steps. ${ }^{33}$ How did the Madison school district system get that way? Under what conditions can it be replicated in other school districts, in other social welfare programs where discretion is an important aspect of citizen-state relations?

33. See, e.g., Elmore, Backward Mapping: Implementation Research and Policy Decisions, 94 POL. SCI. Q. 601 (1979); Elmore, Organizational Models of Social Program Implementation, 26 PUB. POL'Y 185 (1978); Sabatier \& Mazmanian, The Implementation of Public Policy: A Framework for Analysis, 8 POL'Y STUD. J. 538 (1980). 